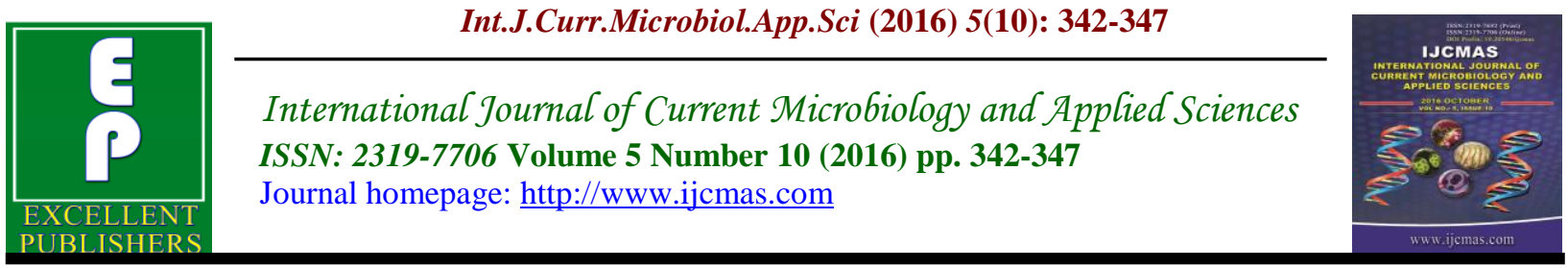

Original Research Article

http://dx.doi.org/10.20546/ijcmas.2016.510.038

\title{
Studies on Cultivation and Biochemical Characterization of Pleurotus florida
}

\author{
P. Vanathi ${ }^{1 *}$, A. Panneerselvam ${ }^{1}$ and R. Senthil Kumar ${ }^{2}$ \\ ${ }^{1}$ P.G and Research Department of Botany and Microbiology, A.V.V.M. Sri Pushpam College \\ (Autonomous), Poondi-613503, India \\ ${ }^{2}$ Department of Microbiology, PG Extension Centre, Bharathidasan University, \\ Perambalur-621107, India \\ *Corresponding author
}

Keywords

Pleurotus florida, Spawn,

Biological

efficiency and

Oyster mushroom.

\begin{tabular}{l}
\hline Article Info \\
\hline Accepted: \\
14 September 2016 \\
Available Online: \\
10 October 2016
\end{tabular}

\section{A B S T R A C T}

Mushrooms are fleshy, spore-bearing reproductive structures of fungi grown on organic substrates and for a long time, have played an important role as a human food due to its nutritional and medicinal properties. Mushrooms are white rot fungi regarded as one of the well known food and possessing various kinds of biochemical compounds. The present study, focused on the cultivation of Pleurotus florida mushroom and analysis of its nutritional status. Pleurotus florida spawn were produced by using sorghum grains. The mushroom was grown on three different substrates like paddy straw, sugarcane trash, and sorghum stem. Among the three substrates paddy straw was gave highest yield $83.4 \%$ of biological efficiency compared with sorghum stem $50.3 \%$ and sugarcane trash $44.7 \%$. The biochemical analysis confirms that the protein, carbohydrates, lipids and amino acids in Pleurotus florida. All the parameters highly present in paddy straw used as a substrate compared with other substrate.

\section{Introduction}

Mushroom cultivation is a profitable agribusiness. Incorporation of non conventional crops in existing agricultural system can improve the economic status of the farmer. Mushrooms are the source of protein, vitamins and minerals and are anticancerous, anti-cholesterol and anti-tumors. Sawdust produced highest yield, biological efficiency and number of fruiting bodies, recommended as a best substrate for oyster mushroom cultivation (Shah et al., 2004).

Mushrooms, because of their special fragrance and texture, have been used for many years in oriental culture as tea and nutritional food (Manzi et al., 1999).

The growth of mushrooms on wheat straw and other substrates, the paddy straw was considered as the best substrate in terms of relative digestibility and nutrient status (Calzada, et al., 1987). Cultivation of Pleurotus sp. on different substrates like saw dust, oat meal etc were studied (Wood and Smith, 1987).

Mushroom mycoprotein contains about 85$95 \%$ water, $3 \%$ protein, $4 \%$ carbohydrates, 
$0.1 \%$ fats, $1 \%$ minerals and vitamins (Tewari, 1986). Mushrooms also contain appreciable amounts of niacin, pantothenic acid and biotin (Subramanian, 1986).

World production of cultivated edible mushroom increased from 170 MT in 1960 to $10,995.5 \times 10^{3} \mathrm{MT}$ in 2007 (Chang, 2007). Mushrooms are now-a-days popularly known as functional foods (Liu and Wang, 2009).

\section{Materials and Methods}

\section{Preparation of spawn bottle}

The half cooked sorghum grains were used as the substrate for mushroom spawn. Sorghum grains were filled in the ploy propylene bag again sterilized in a pressure cooker at $15 \mathrm{lbs}$ pressure for 20 minutes. These sterilized Polypropylene bags were stored in a laminar flow, which previously treated with alcohol and UV radiation.

The mycelium of $P$. florida which appeared in the Petri plates was inoculated in the bottle containing sorghum grains that were closed with non absorbent cotton plug and stored in the "Kalan Kudil" for 15 days.

\section{Preparation of mushroom bed}

Mushroom beds were prepared using paddy straw, sorghum stem and sugarcane trash used as substrates to find out the yield and quality of mushroom. The one spawn bottle can use to prepare two mushroom beds. In our study three beds were prepared to each substrate; size of each bed was $30 \times 60 \mathrm{~cm}$.

The poly propylene bag method was chosen for mushroom culture. Substrates (paddy straw, sorghum stem and sugarcane trash) were chopped into pieces of 2-3 inches length and soaked in water for 8 hours and water was then drained off from the paddy straw. After words the substrates were sterilized using vertical autoclave at $15 \mathrm{lbs}$ pressure for $20 \mathrm{~min}$. The sterilized substrates were placed on a wire mesh net for draining off excess water. Polythene bags in the size of $30 \times 60 \mathrm{~cm}$ were procured and filled with the treated paddy straw as follows.

A polypropylene bag was tied at one end and sterilized substrates were filled through the open end for about $5 \mathrm{~cm}$. A handful of spawn from the bottle was spread towards the periphery of this layer. Over the spawn some more paddy straw was put and pressed lightly. This process was repeated five times. The mouth of polypropylene bag was rolled and closed with toe threads. Holes were made over the polypropylene bags for aeration. One bottle of spawn was enough to inoculate two bags and they were kept in a ventilated dark chamber. After 15 days it was observed that the mycelia of Pleurotus florida had grown all over the substrates and sprayed water 3-4 times per day.

\section{Harvesting}

The matured fruit body was harvested by hand pick up of clock wise or anti clock wise rotation before spraying of water. The harvested fruit body was weighed and recorded substrate wise individually. The same procedure was followed up to $2^{\text {nd }}$ and $3^{\text {rd }}$ harvesting. Then calculate the total yield and percentage of biological efficiency. Also harvested fruit body was used for further biochemical analysis.

\section{Biochemical Analysis}

The various biochemical analysis was carried out in fruit body of Pleurotus florida harvested from different substrates such as paddy straw, sorghum stem and sugarcane trash. The following biochemical parameters 
analysed by using standard procedures like quantitative estimation of total protein by Lowery et al., 1951, quantitative estimation of free amino acid by Jayaraman, 1981, quantitative estimation of total carbohydrate by Dubois et al., 1956 and extraction of lipid-Liplid analysis by Sato and Murata, 1988.

\section{Results and Discussion}

Mushrooms are protein rich ecofriendly food and it is cultivable initially as an empirical process. But the scientific understanding of mushroom cultivation will help in improving the cultivation technology. Rajini Bisaria et al., (1987) cultivated Pleurous sajorcaju on different agro wastes like paddy straw, wheat straw etc and they have reported maximum yield with paddy straw. Singh et al. (1995) suggested the use of sugarcane trash for the production of oyster mushroom.

The wide range of plant waste that have been reported include sawdust, paddy straw, sugarcane baggage, corn stalk, corn cobs, waste cotton, leaves and pseudo stem of banana, water hyacinth, duck weed, rice straw etc. and does not require costly processing method and enrichment material (Mondal, 2010; Stanley, 2011).

Mushrooms with their pleasant flavour, texture and high productivity per unit area have been recognized as an exceptional food source to alleviate malnutrition in developing countries. High nutritional values of oyster mushrooms with protein (25-50\%), fat (2-5\%), sugars $(17-47 \%)$, mycocellulose $(7-38 \%)$ and minerals (potassium, phosphorus, calcium, sodium) of about 8-12\% (Stanley et al., 2011).

Karuppuraj et al., (2014) reported that the yield improvement of $P$. florida on unexplored locally available lignocellulosic materials such as paddy straw, reeds, banana stem, sugar cane leaves, sugar cane bagasse milled and crushed coir pith sorghum husk and sunflower stem was used.

Similarly, in the present study, mycelia of $P$. florida was fast grew on sorghum grains on $16^{\text {th }}$ days. After that spawn was used to further cultivation. In the present investigation, P. florida was well grew on all the three substrates and formed mycelium meanwhile $P$. florida was fastest spawn run on paddy straw substrate $\left(16^{\text {th }}\right.$ day) followed by sugarcane trash $\left(19^{\text {th }}\right.$ day) and sorghum stem $\left(20^{\text {th }}\right.$ day). The pin head formation also first formed in paddy straw substrate on $19^{\text {th }}$ day followed by sugarcane trash $23^{\text {rd }}$ day and sorghum stem $25^{\text {th }}$ day. The number of fruit bodies also recorded (Table 1).

In the present study, Pleurotus florida was gave highest yield in paddy straw used as a substrate $(834 \mathrm{~g})$. The moderate yield was observed in sorghum stem used as a substrate $(503 \mathrm{~g})$. The lowest yield was recorded in sugarcane trash used as a substrate (447 g) (Table 2).

In the present study, correlated with Karuppuraj et al., (2014) the maximum bio efficiency of $P$. florida was obtained from paddy straw (124.50\%) followed by reeds (100.30\%).

Nine spent mushroom substrate were analyzed for reduction of cellulose, hemicelluloses, lignin, and acid detergent lignin. Sugar cane bagasse milled recorded for highest reduction of cellulose $(29.40 \%)$ and banana stem for hemicelluloses $(25.77 \%)$. Coir pith recorded for the highest reduction of lignin $(24.36 \%)$ and acid detergent fibre $(15.31 \%)$. The reeds can be utilized for successful cultivation of $P$. florida at commercial level than the paddy straw. 
Table.1 Cultivation of Pleurotus florida on various substrates

\begin{tabular}{|c|c|c|c|c|}
\hline S. No & Substrates & $\begin{array}{c}\text { Spawn run } \\
\text { day }\end{array}$ & $\begin{array}{c}\text { Pinhead formation } \\
\text { Day }\end{array}$ & $\begin{array}{c}\text { Mean no of } \\
\text { Fruit bodies }\end{array}$ \\
\hline 1 & Paddy straw & 16 & 19 & 12 \\
\hline 2 & Sorghum stem & 20 & 25 & 8 \\
\hline 3 & Sugarcane trash & 19 & 23 & 7 \\
\hline
\end{tabular}

Table.2 Production of Pleurotus florida using different substrates

\begin{tabular}{|c|c|c|c|c|c|c|}
\hline \multirow[t]{2}{*}{ S. No } & \multirow[t]{2}{*}{ Substrates } & \multicolumn{3}{|c|}{ Mushroom production (g) } & \multirow{2}{*}{$\begin{array}{c}\text { Total } \\
\text { production }(\mathrm{g})\end{array}$} & \multirow{2}{*}{$\begin{array}{c}\text { B.E in } \\
(\%)\end{array}$} \\
\hline & & $1^{\text {st }}$ harvest & $2^{\text {nd }}$ harvest & $3^{\text {rd }}$ harvest & & \\
\hline \multirow{3}{*}{1} & \multirow{3}{*}{ Paddy straw } & 410 & 270 & 185 & 865 & 86.5 \\
\hline & & 436 & 245 & 166 & 847 & 84.7 \\
\hline & & 400 & 230 & 160 & 790 & 79.0 \\
\hline \multirow{3}{*}{2} & \multirow{3}{*}{$\begin{array}{l}\text { Sorghum } \\
\text { Stem }\end{array}$} & 300 & 124 & 100 & 524 & 52.4 \\
\hline & & 246 & 150 & 110 & 506 & 50.6 \\
\hline & & 230 & 130 & 120 & 480 & 48.0 \\
\hline \multirow{3}{*}{3} & \multirow{3}{*}{$\begin{array}{l}\text { Sugarcane } \\
\text { Trash }\end{array}$} & 146 & 190 & 126 & 462 & 46.2 \\
\hline & & 200 & 126 & 120 & 446 & 44.6 \\
\hline & & 175 & 150 & 110 & 435 & 43.5 \\
\hline
\end{tabular}

Table.3 Nutrient contents of Pleurotus florida on various substrates

\begin{tabular}{|c|l|c|c|c|c|}
\hline S. No & \multicolumn{1}{|c|}{ Substrates } & $\begin{array}{c}\text { Protein } \\
\mathrm{mg} / \mathrm{g}\end{array}$ & $\begin{array}{c}\text { Carbohydrate } \\
\mathrm{mg} / \mathrm{g}\end{array}$ & $\begin{array}{c}\text { Amino acid } \\
\mathrm{mg} / \mathrm{g}\end{array}$ & $\begin{array}{c}\text { Lipid } \\
\mathrm{mg} / \mathrm{g}\end{array}$ \\
\hline 1 & Paddy straw & 22.7 & 10.1 & 9.1 & 4.3 \\
\hline 2 & Sugarcane trash & 20.0 & 6.7 & 5.2 & 0.4 \\
\hline 3 & Sorghum stem & 22.2 & 4.3 & 7.6 & 2.0 \\
\hline
\end{tabular}

Krishna kumar et al., (2009) the highest percent biological efficiency of $P$. florida was recorded on paddy straw (77.35) followed by areca nut pericarp (57.00), coconut leaf (51.25) and in rest of substrate biological efficiency was less than $50 \%$. Mostafa et al., (1991) analysed the chemical composition of $P$. florida and $P$. sajorcaju. The samples were analysed for their moisture total nitrogen, total carbohydrates, crude fat, crude fibre and ash using the standard methods. Similarly, in the present investigation, the maximum content of protein $(22.7 \mathrm{mg} / \mathrm{g})$, carbohydrate $(10.1$ $\mathrm{mg} / \mathrm{g})$, amino acid (9.1 mg/g) and lipid (4.3 $\mathrm{mg} / \mathrm{g}$ ) was observed in paddy straw used as a substrate. The moderate contents of protein $(22.2 \mathrm{mg} / \mathrm{g})$ and amino acid (7.6 $\mathrm{mg} / \mathrm{g}$ ) observed sorghum stem used as a substrate and carbohydrate $(6.7 \mathrm{mg} / \mathrm{g})$ observed sugarcane trash used as a substrate. The minimum content of protein $(20 \mathrm{mg} / \mathrm{g})$, carbohydrate $(4.3 \mathrm{mg} / \mathrm{g})$, lipid $(2 \mathrm{mg} / \mathrm{g})$ was recorded in sorghum stem used as a substrate and amino acid (5.2 $\mathrm{mg} / \mathrm{g})$ observed in sugarcane trash used as a substrate (Table 3). 
Ghosh et al., (1991) analysed the nutritive value of $P$. citrinopileatus at different stages of growth cycle and compared with that of tropical oyster mushroom. Protein content was more at I and II stage but fell thereafter.

Breene (1990) and Cokuner and Ozdemir (2000) reported that the protein contents of mushroom range from 19 to $39 \mathrm{~g}$ in $100 \mathrm{~g}$ dried matter. Nuhualam et al., (2007) reported that the 4 species $P$. ostreatus, $P$. sajor-caju, P. florida and Calocybe indica protein 20-25\% rich in mushroom, carbohydrate content ranged from $37-48 \%$ and low amount of lipid $4.5 \mathrm{mg} / \mathrm{g}$.

\section{References}

Breene, W.M. 1990. Nutritional and medicinal value of specialty mushrooms. J. Food protect, 53: 883894.

Calzada, J.F., Deleon, R., De arriola, M.C., and Rala, C. 1987. Growth of mushroom on wheat straw and pulp strain selection, Biological wastes, 30: $217-226$.

Chang, S.T. 2007. Development of the World Mushroom Industry and its roles in human health. In: Rai RD, Singh SK, Yadav MC, Tewari RP, editors. Mushroom biology and biotechnology. Solan: Mushroom Society of India, National Research Centre for Mushroom.

Cokuner, Y. and Ozdemir. Y. 2000. Acid and Edta blanching effects on the essential element content of mushrooms (Agaricus bisporous) J. Sci. Food Agri., 80: 2074-2076.

Dubios, M., Gilles, K.A., Hamilaton, J.K., Robers, P.A., and Smith, F. 1956. Colorimetric methods for determination of sugar and related substances. Anal. Chem.., 28: 350-356.

Ghosh, N., Mitra, D.K., and Chakaravarthy,
D.K. 1991. Composition analysis of tropical white oyster mushroom $(P$. citrinopileatus. Ann. App. Biol., 118: 527-531.

Jayaraman, J. 1981 Calorimetric estimation of amino acid In: Laboratory manual in Biochemistry, Wiley Eastern Ltd., New Delhi, pp:64

Karuppuraj, V., S.Chandra Sekarenthiran and K. Perumal. 2014. Yield improvement of Pleurotus florida fruiting bodies from locally available unexplored lignocellulosic substrates. Int. J. Curr. Microbiol. Appl. Sci., 3(10): pp. 985-990.

Liu, G.Q., Wang, X.L. 2009. Selection of a culture medium for reducing costs and intracellular polysaccharide production by Agaricus blazei AB 2003. Food Technol. Biotechnol., 47: 210-214.

Lowery, O.H., Rosebrough, N.J. and Randall, R.J. 1951. Protein measurement with the folin phenol reagent. J. Biol. Chem., 193: 265-275.

Manzi, P., Gambelli, L., Marconi, S., Vivanti, V., Pizzoferrato, L. 1999. Nutrients in edible mushroom: An inter-species comparative study. Food Chem., 65: 477-482.

Mondal, S.R., Rehana, M.J., Noman, M.S., Adhikary, S.K. 2010. Comparative study on growth and yield performance of oyster mushroom (Pleurotus florida) on different substrates. J. Bangladesh Agri. Univ., 8(2): 213 -220.

Mostafa, H., El-Kattan, Zakia, A. Helmy, Mohamed Abd El-leitty and Khalid, A. Abdelkawi. 1991. Studies on cultivation techniques and chemical composition of oyster mushrooms,

Nuhu Alam, Shahdat, Abul Khair, Ruhul Amin and Asuduzzaman, K. 2007. Comparative effects of oyster mushrooms on Plasma lipid profile of 
hypercholesterolaemic

rats

Bangladesh, J. Mushroom, 1: 15-22.

Rajini Bisaria, Madan, M. and Bisaria, V.S. 1987. Biological efficiency and nutrive value of Pleurotus sajor-caju cultivated on different agro wastes. Biol. Wastes, 19: 239-255.

Sato, N. and Murata, N. 1988. Membrane lipids:In methods in Enzymology (Eds.), Packer, L. and Glazer, A.N.,167: 251-259.

Shah, Z.A., Ashraf, M., and Ishtiaq, M.Ch. 2004. Comparative study on cultivation and yield performance of Oyster Mushroom (Pleurotus ostreatus) on different substrates (wheat straw, leaves, saw dust. Pak. J. Nutri., 3(3): 158-160.

Singh, A.K., Swasthi, S.K., and Bharat Raj. 1995. Utilization of sugar cane trash [Dried leaves) for the production of Oyster mushroom Pleurotus florida
Mushroom Res., 4: 35-38.

Stanley, H.O., Umolo, E.A., Stanley, C.N. 2011. Cultivation of oyster mushroom (Pleurotus pulmonarius) on amended corncob substrate. Agri. Biol. J. North America, 2(8): 1239 -1243.

Subramanian, T.R. 1986. Nutritive value Mushroom Extension bulletin. Indian Institute of Horticulture Res., India 8: 36.

Tewari, R.P. 1986. Mushroom cultivation. Extension Bulletin. Indian Institute of Horticulture Research, Banglore, India, 8: 36.

Wood, D.A., and Smith, J.F. 1987. The cultivation of mushroom (Part III), Reproduced form essay in Agricultural and food Microbiology (Eds.) Norris, J.R. and G.L. Pettipher, John willey and sons Ltd.

\section{How to cite this article:}

Vanathi, P., A. Panneerselvam and Senthil Kumar, R. 2016. Studies on Cultivation and Biochemical Characterization of Pleurotus florida. Int.J.Curr.Microbiol.App.Sci. 5(10): 342347. doi: http://dx.doi.org/10.20546/ijcmas.2016.510.038 